\title{
Analysis of the feasibility of the use of CDW as a low-environmental- impact aggregate in conglomerates
}

\author{
Alejandra Vidales Barriguete ${ }^{a, *}$, Mercedes del Río Merino ${ }^{\mathrm{b}}$, Evangelina Atanes Sánchez ${ }^{c}$, \\ Carolina Piña Ramírez ${ }^{\mathrm{b}}$, Carmen Viñas Arrebola ${ }^{\mathrm{a}}$ \\ ${ }^{a}$ Universidad Politécnica de Madrid, Escuela Técnica Superior de Edificación, Departamento de Tecnologia de la Edificación, Avenida Juan de Herrera, 6, 28040 Madrid, Spain \\ ${ }^{b}$ Universidad Politécnica de Madrid, Escuela Técnica Superior de Edificación, Departamento de Construcciones Arquitectónicas y su Control, Avenida Juan de Herrera, 6 , 28040 \\ Madrid, Spain \\ ${ }^{c}$ Universidad Politécnica de Madrid, Escuela Técnica Superior de Ingeniería y Diseño Industrial, Departamento de Ingeniería Mecánica, Química y Diseño Industrial, Ronda de \\ Valencia, 3, 28012 Madrid, Spain
}

\begin{abstract}
A B S T R A C T
This article summarises the first phase of a research project that analyses the feasibility of re-using plastic cable waste (pellets) as a means of reducing the environmental impact of buildings. The aim is to find a use for this plastic waste in construction materials, specifically gypsum matrices, by characterising the physical and chemical properties of the raw material and the physical and mechanical properties of the compounds. The results obtained show that the addition of up to $70 \%$ of the weight of the gypsum in aggregate improved some of the properties tested, such as surface hardness and capillary absorption, and significantly reduced the use of gypsum and water.
\end{abstract}

\section{Introduction}

The entry into force of the EU's Waste Framework Directive (2008/98/EC) changed the approach to waste management in Europe by prioritising prevention and re-use over disposal and recovery [1]. In the construction industry, this new approach involves introducing a new environmentally-oriented paradigm [2], in other words, a "cradle to cradle" circular model in which resource management strategies are based on a comprehensive study of the "life cycle" of materials [3] and on the reincorporation of market waste [4].

Estimates suggest that approximately $35 \%$ of the waste generated in Europe comes from the construction industry (construction and demolition waste, or CDW) [5,6]. Although this has decreased in recent years, mainly due to the effects of the economic crisis in Europe, there is a pressing need to find new ways of reusing and/or recycling this waste [7]. Plastic is one of the most abundant CDW products, and at the same time one of the most difficult to recycle. According to indicators used by the association of European plastics manufacturers, Plasticseurope, more than $20 \%$ of all plastic

\footnotetext{
* Corresponding author at: Technical University of Madrid, Avda. Juan de Herrera, 6, 28040 Madrid, Spain.

E-mail address: alejandra.vidales@upm.es (A. Vidales Barriguete).
}

manufactured is used in the construction sector; this means about 10 million tons of material per year that will eventually become CDW [8].

For many years, plastic waste has been sent to landfills along with other CDW materials, but this has begun increasingly problematic due to the decrease in available areas and rising costs [9]. Although there are currently numerous mechanical (when the formulation is known) and chemical (decomposition of the material in monomers for use in new polymerisation processes) methods and techniques for recycling plastic, the lack of homogeneity, that is, the presence of mixed thermoplastic and thermoset materials, complicates these transformation processes.

Sustainability is now one of the main focuses of the construction materials industry [10,11]. The study, development and use of alternative materials is one of the most important factors in the evolution of the construction sector $[12,13]$, and adding waste product to traditional building materials is a good way of improving sustainability.

We found many studies analysing different ways of solving this problem by incorporating plastic waste products in construction materials. These materials not only reduce the amount of waste in landfills, but are also cheaper, lighter, and provide better thermal insulation than traditional products for the construction of low-income housing $[14,15]$. Some researchers have focussed on 


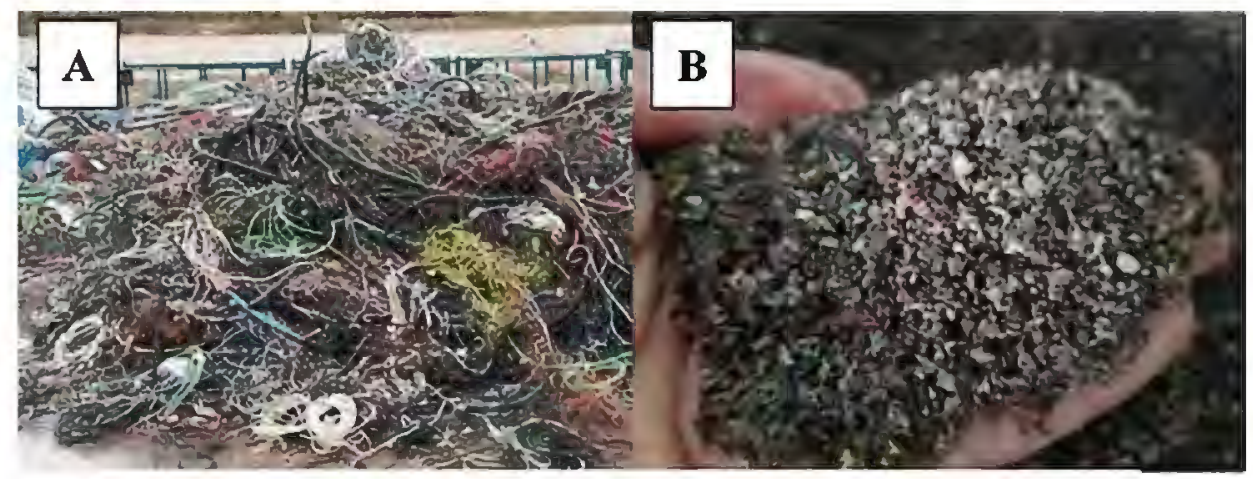

Fig. 1. (A) The cables awaiting recycling in the recycling plant. (B) Plastic waste productobtained after recycling. Source: Lyrsa Âlava (Spain).

the use of discarded plastic containers and packaging as an additive in non-load-bearing construction elements, bricks, blocks and cement boards, while other have manufactured lighter, more durable concrete blocks and flooring using waste from PVC pipes, vehicle wheels and bags of milk [16-19].

We also found other studies reporting the use of different polymers, such as polyethylene fibres, polypropylene fibres, polyvinyl alcohol (PVA), etc., as additives or replacements in cement and gypsum matrices [20-24].

One of the most widely used traditional construction materials is gypsum, which is abundant, versatile and inexpensive [25], and is calcined at low temperatures, which means that less energy is needed during the manufacturing process compared to other building products [26].

Despite this, the overall process of manufacturing gypsum has a negative impact on the environment insofar as gypsum mining or quarrying damages the soil, the end product is obtained by depleting non-renewable natural resources (raw gypsum and water), the raw materials must be heated in kilns that generate leachates, and the whole process involves extensive transportation. For this reason, many researchers have attempted to improve the sustainability of the product by incorporating XPS, rubber, crushed EPS, or polystyrene to the matrix to reduce the consumption of raw material (gypsum). These aggregates may also modify some of the properties of gypsum compounds, such as reducing the density of the material, improving its thermal properties, or increasing its deformation capacity, among others [27-30].

However, we could find no studies describing the incorporation of pellets from recycled cables as aggregates in gypsum pastes. This prompted us to undertake this study to evaluate the reuse of these pellets as aggregate in gypsum compounds in order to reduce the environmental impact.

\section{Materials and methods}

\subsection{Materials}

The materials used in this study include gypsum/plaster, water and plastic waste from cables.

We used fast-setting gypsum and gypsum binders (plaster), classed as B1 and A respectively according to UNE EN 13279-1 [31], obtained from the commercial manufacturer Placo. The real density of the material, measured by helium pycnometry, was $2.81 \mathrm{~g} / \mathrm{cm}^{3}$ for the gypsum and $2.72 \mathrm{~g} / \mathrm{cm}^{3}$ for the binder.

The water used was taken from the Canal de Isabel II in Madrid and meets the technical characteristics established in the UNE EN 13279-2 standard [32].

The waste was used in the same condition it was obtained from the Lyrsa Âlava recycling plant (Spain), after the process the dis- used cables undergo to recuperate the wire core. The pellets (PR) are composed of a heterogeneous mixture of thermoset and thermoplastic polymers (Fig. 1) and have a real helium pycnometry density of $1.35 \mathrm{~g} / \mathrm{cm}^{3}$.

The PR was sieved in order to measure the particle size distribution using the mesh sizes indicated in UNE-EN 933-1:2012 [33]. The size distribution curve showed that $100 \%$ of the sample passed through the $4 \mathrm{~mm}$ sieve. Most (69.1\%) particles measured between 1 and $2 \mathrm{~mm}$, and $97.5 \%$ measured over $0.5 \mathrm{~mm}$ (Fig. 2).

\subsection{Preparation of test samples}

Initially, following the indications in the UNE EN 13279-2 [32] and UNE 102,042 [34] standards, we prepared a series of three $40 \times 40 \times 160 \mathrm{~mm}^{3}$ prismatic gypsum samples with a water/gypsum ratio of 0.8 and 1.0 (called Y0.8-Y1.0), and plaster samples with a water/plaster ratio of 0.8 and 0.9 (called E0.8-E0.9).

The highest percentage of PR to be added to the pastes was chosen on the basis of obtaining a workable paste. According to del Río Merino [35], "the workability of the gypsum depends on its moldability, its variable consistency, its adjustable fast setting time, its setting expansion, its initial strengths and its modifiability or workability on pre-set elements". The moldability, the setting expansion and the modifiability of the pastes were visually observed during the manufacture of the test samples. Consistency was determined using the vibrating table method, start of setting was determined using the Vicat cone method, and strength was determined as detailed in Section 2.3.2 (hardness, and flexural and compressive strength). All tests were performed in accordance with UNE EN 13279-2 [32]

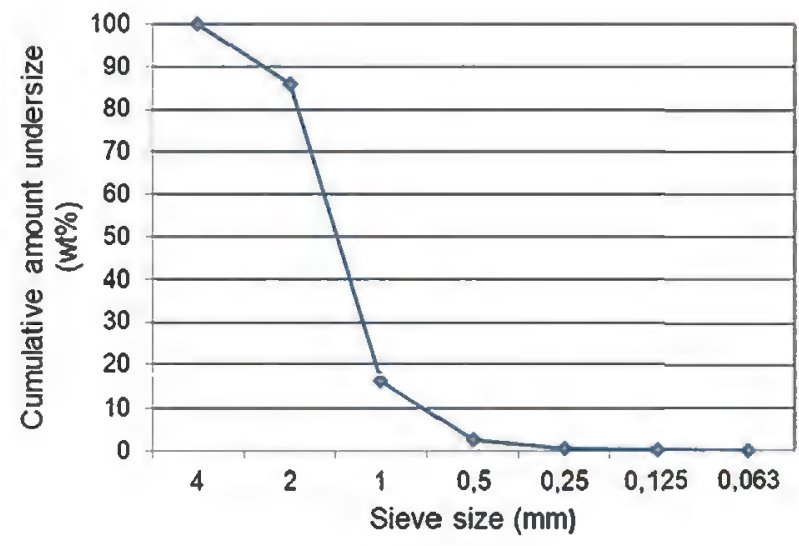

Fig. 2. Particle size distribution of the pellets. 
Table 1

Composition of compounds.

\begin{tabular}{|c|c|c|c|c|c|c|}
\hline Name & Gypsum (\%) & Plaster (\%) & Water (\%) & Pellets (\%) & Bulk density $\left(\mathrm{g} / \mathrm{cm}^{3}\right)$ & Weight at 7 days (g) \\
\hline Y0.8 & 100 & & 80 & 0 & 0.998 & 256.50 \\
\hline Y0.8-50PR & 100 & & 80 & 50 & 1.019 & 261.80 \\
\hline Y0.8-60PR & 100 & & 80 & 60 & 1.027 & 263.60 \\
\hline Y0.8-70PR & 100 & & 80 & 70 & 1.012 & 259.70 \\
\hline Y1.0 & 100 & & 100 & 0 & 0.859 & 220.40 \\
\hline Y1.0-50PR & 100 & & 100 & 50 & 0.937 & 240.60 \\
\hline Y1.0-60PR & 100 & & 100 & 60 & 0.917 & 235.30 \\
\hline Y1.0-70PR & 100 & & 100 & 70 & 0.936 & 240.10 \\
\hline E0.8 & & 100 & 80 & 0 & 0.989 & 253.40 \\
\hline E0.8-50PR & & 100 & 80 & 50 & 1.009 & 258.40 \\
\hline E0.8-60PR & & 100 & 80 & 60 & 1.022 & 261.90 \\
\hline E0.8-70PR & & 100 & 80 & 70 & 1.015 & 260.10 \\
\hline E0.9 & & 100 & 90 & 0 & 0.929 & 238.20 \\
\hline E0.9-50PR & & 100 & 90 & 50 & 0.986 & 253.20 \\
\hline E0.9-60PR & & 100 & 90 & 60 & 0.970 & 248.60 \\
\hline E0.9-70PR & & 100 & 90 & 70 & 0.967 & 247.70 \\
\hline
\end{tabular}

On this basis, a series of test samples was made with $50 \%-60 \%-$ $70 \%$ of PR added to the weight of the gypsum or plaster. The composition of the compounds is shown in Table 1.

\subsection{Experimental plan}

A 2-phase experimental plan was designed and carried out in the chemistry laboratory of the Higher Technical School of Engineering and Industrial Design, and in the materials laboratory of the Higher Technical School of Building Engineering of the Polytechnic University of Madrid.

The test samples were prepared by mixing the gypsum or plaster with the PR before pouring it into the water and mixing (to prevent the waste from floating). Following this, they were kept in a laboratory atmosphere for 7 days (temperature of $23 \pm 2{ }^{\circ} \mathrm{C}$ and relative humidity of $35 \pm 5 \%$ ), dried for $24 \mathrm{~h}$ in an oven at a temperature of $40 \pm 2{ }^{\circ} \mathrm{C}$ until constant mass, and cooled in a desiccator to laboratory temperature, as indicated in UNE-EN 13279-2 [32].

2.3.1. Phase 1: Physical-chemical characterisation of the raw material

Elemental, X-ray diffraction and thermogravimetric analyses were carried out.
Elemental analysis: the chemical composition of the test samples was analysed by X-ray fluorescence spectrometry (XRF) using a Philips-Magic $1 \mathrm{~kW}$ spectrometer. The test samples were covered with Mylar plastic and analysed in a helium atmosphere (Fig. 3).

$X$-ray diffraction: a Siemens D5000 Diffraktometer with $\mathrm{Cu} \mathrm{Ka}$ radiation $(1,2)$ and graphite monochromator was used to obtain the diffraction profile of the gypsum and plaster (Fig. 4).

Thermogravimetry: Mass loss or gain at different temperatures was measured to determine the dynamic thermal and gravimetric parameters of the gypsum, plaster and pellets. The equipment used was a TA Instruments SDT Q600 thermobalancer set to $100 \mathrm{ml} / \mathrm{min}$ of air, and the specimen was analysed at $10^{\circ} \mathrm{C} / \mathrm{min}$ from ambient temperature to $1000^{\circ} \mathrm{C}$ (Fig. 5).

\subsubsection{Phase 2: Tests on gypsum and PR test samples}

Shore $C$ surface hardness, flexural and compressive strength, and capillary absorption were measured. We also studied the microscopic crystalline structure of these compounds to understand the behaviour of the mixtures under test conditions.

Shore C surface hardness (UNE 102,042 [34]): a Shore C durometer was used to measure hardness on the 2 longitudinal sides of the test samples (Fig. 6).

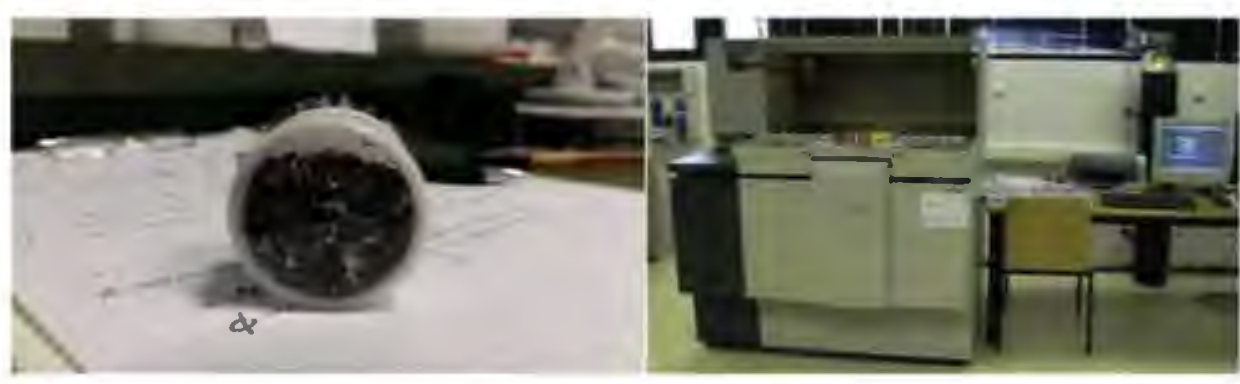

Fig. 3. Elementary analysis.

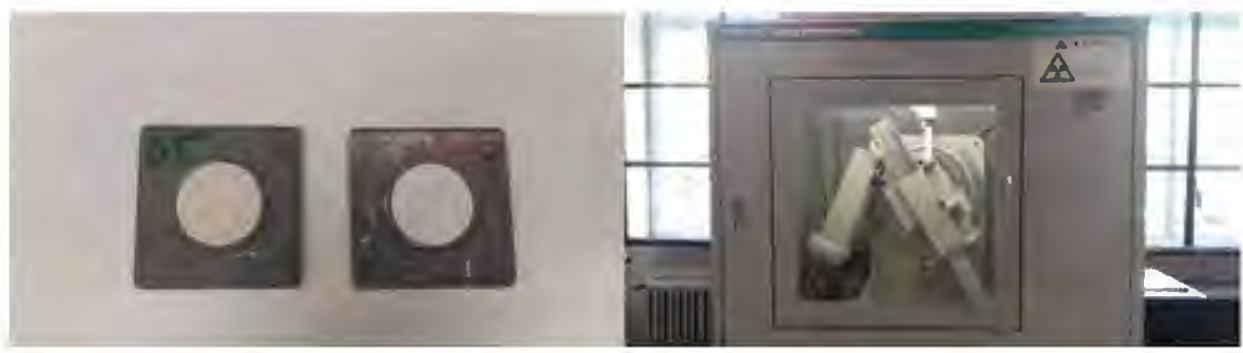

Fig. 4. X-ray diffraction test. 


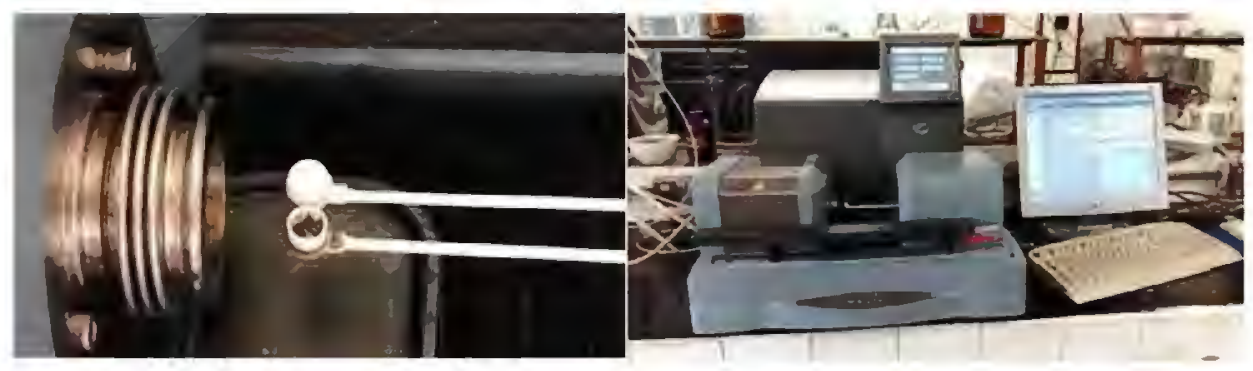

Fig. 5. Thermogravimetric analysis.

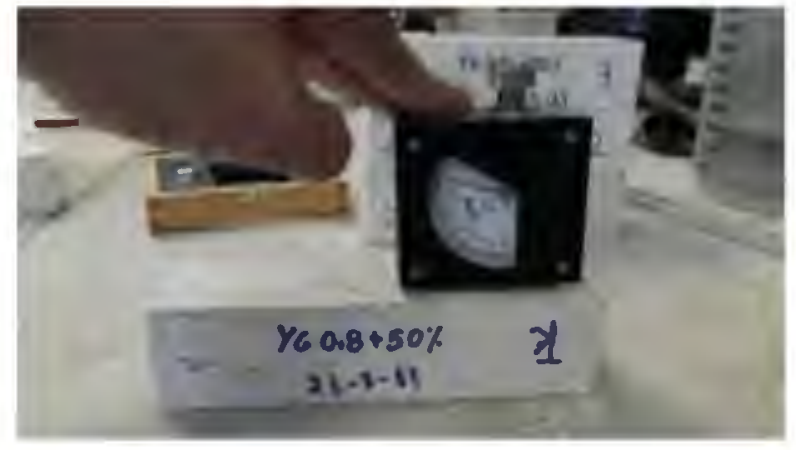

Fig. 6. Shore C surface hardness test.

Flexural and compressive strength (UNE-EN 13279-2 [32]): the Ibertest Autotest 200 was used for this purpose. This device applies a load until breakage and registers the breakage point obtained in the computer program (Fig. 7).

Capillary absorption: the water absorption test was carried out according to the RILEMTC 25-PEM standard [36] used in other studies $[37,38]$. The test specimens, previously weighed, were placed vertically in a container with $1 \mathrm{~cm}$ of water, and capillary absorption was measured at $1 \mathrm{~min}$ intervals. After $10 \mathrm{~min}$, each of the marks was measured and the specimen was reweighed (Fig. 8).

Microscopy: Microscopic analysis was performed using the ESEM-Quanta FEG-250 environmental scanning electron microscope. This instrument can analyse untreated samples measuring up to $50 \mathrm{~mm}$, and allowed us to study the morphology and crystalline texture of the samples, as well as the pellet interface (Fig. 9).

\section{Results and discussion}

\subsection{Phase 1: Physical-chemical characterisation of the raw material}

The physical-chemical characterisation of the raw material confirmed that the gypsum and plaster conformed to the manufacturer's specifications. In the case of the PR, the characterisation revealed its complex chemical nature consisting of a mixture of very different polymers. The following is a summary of the most significant results obtained.

\subsubsection{Elemental analysis}

The results of the X-ray fluorescence elemental analysis are shown in Table 2 (expressed as oxides):

In the PR, organic matter accounts for $92.6 \%$ of the composition. The presence of chlorine is interesting. This could correspond to PVC, one of the most common polymers in electric cables [39]. The presence of copper and aluminium could be due to metallic residue from the wire cable.

\subsubsection{X-ray diffraction}

The results of the gypsum and plaster X-ray diffractogram are shown in Fig. 10. In both cases, calcium sulphate hemihydrate ( $\mathrm{CaSO}_{4} \cdot 0.5 \mathrm{H}_{2} \mathrm{O}$ ) was identified, but dihydrate was absent [40].

\subsubsection{Thermogravimetry}

Fig. 11 shows the mass loss observed in the samples at different temperatures, together with the associated thermal effects.

The gypsum and plaster test samples show a total weight loss of less than 10\%; after an initial loss $(<1 \%)$ due to weakly associated humidity, a second weight loss (endothermic) of around $6 \%$ observed between 100 and $200^{\circ} \mathrm{C}$ can be associated with the dehydration of gypsum hemihydrate $\left(\mathrm{CaSO}_{4} \cdot 1 / 2 \mathrm{H}_{2} \mathrm{O}\right)$ to obtain anhydrous calcium sulphate or anhydrite III, which is produced below $200^{\circ} \mathrm{C}$. The XRD and thermal analysis results indicate that both test samples are chemically similar, but differ fundamentally in their granulometry $(11,35)$.

The PR, on the other hand, is thermally stable up to a temperature of approximately $200{ }^{\circ} \mathrm{C}$, but from that point to $700^{\circ} \mathrm{C}$ presents a heavy loss of mass of $84 \%$. In this temperature interval, several peaks corresponding to the oxidative thermal decomposition of the components of the sample are observed, showing the heterogeneity of polymers present $[41,42]$.

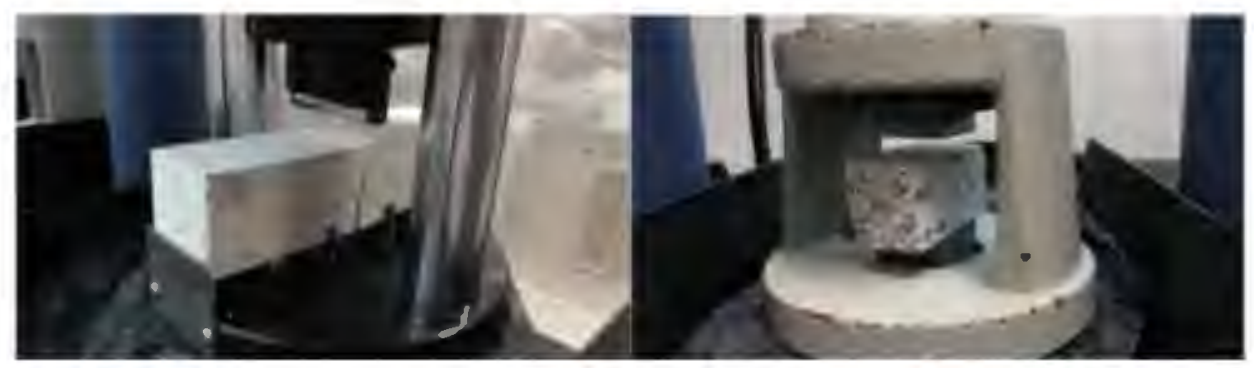

Fig. 7. Flexural and compression test. 


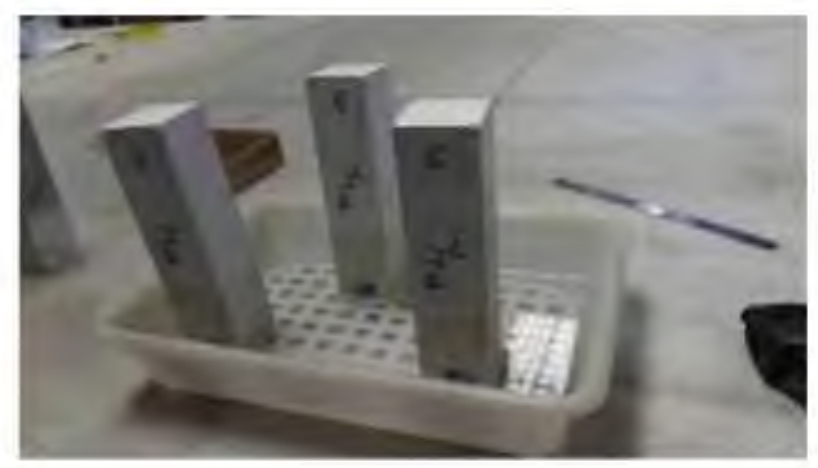

Fig. 8. Capillary absorption test.

\subsection{Phase 2: Tests on gypsum and PR test samples}

Making the test samples allowed us to determine the maximum percentage of PR to be added to the mixture to achieve the workability parameters established in Section 2.2. The consistency of the mixtures determined by the vibrating table test are shown in Table 3, and the start of setting measured using the Vicat cone method is shown in Fig. 12.

The vibrating table test showed that none of the compounds met the $160-165( \pm 5) \mathrm{mm}$ [32] consistency required for premixed gypsums, but provided the following data: the higher the percentage of PR, the better the consistency of the paste; the gypsum test samples showed greater consistency with respect to plaster test samples; in both plaster and gypsum samples, the pastes with the least amount of water in their composition presented greater consistency. The compound closest to that indicated in the EU regulation was E 0.9-70PR (170.50) and the one furthest from the requirements was E 0.8-50 PR (239.50).

The more PR added to the mixture, the faster the start of setting, which was $45 \%$ faster in compounds with $50 \% \mathrm{PR}, 53 \%$ in those with $60 \% \mathrm{PR}$, and $62 \%$ in those with $70 \%$ PR. The gypsum compounds started setting approximately $14 \%$ faster than the plaster compounds. The addition of water to both plaster and gypsum samples slowed down start of setting by approximately $17 \%$ in the 0.8 ratio compared to 0.9 , and by approximately $32 \%$ in the 0.8 ratio with respect to 1.0 .

The compound with the fastest setting time was Y 0.8-70 PR (5 $\mathrm{min}$ ) and the slowest was Y 1.0-50 PR (11 min).

These results, therefore, confirmed the difficulty of adding more than $70 \% \mathrm{PR}$ to the mixture.

\subsubsection{Minimisation of environmental impact}

The amount of raw material used for each series of test samples is shown in Fig. 13.
Table 2

Elemental analysis of the pellets.

\begin{tabular}{lc}
\hline Compound & Pellet \\
\hline Concentration [\%] (greater than 0.5\%) & \\
Organic mat. & 92.6 \\
Aluminium & 1.9 \\
Chlorine & 1.3 \\
Bromine & 1.2 \\
Copper & 0.8 \\
Calcium & 0.7 \\
Silicon & 0.5 \\
\hline
\end{tabular}

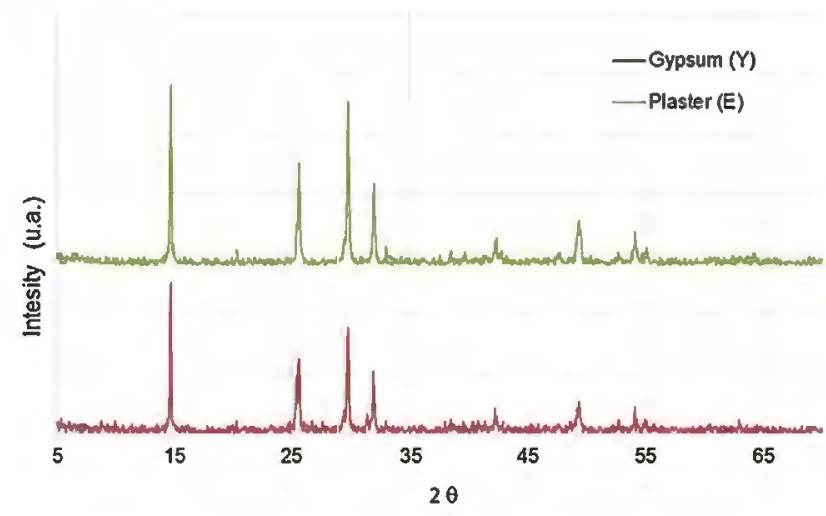

Fig. 10. X-ray diffractogram of gypsum and plaster.

The more PR added to the mixtures, the less gypsum and water is used, until the gypsum and water content was reduced to around $25 \%$ in the mixtures with $50 \% \mathrm{PR}$ and approximately $37.5 \%$ in the mixtures with $60 \%$ and $70 \% \mathrm{PR}$.

\subsubsection{Surface hardness}

Fig. 14 shows the results obtained in the Shore $C$ surface hardness test.

Although the surface hardness increases as more PR is added to the matrix (with the exception of some compounds), it does so to a different extent in each compound. Therefore, surface hardness increased by $26.6 \%$ with respect to the reference value in gypsum, but only by $4.3 \%$ in the case of plaster. Despite this, the plaster compounds are approximately $9 \%$ harder than the gypsum compounds.

The surface hardness decreases as the amount of water in the composition increases, so that, with respect to compounds with a 0.8 ratio, hardness in compounds with a ratio of 0.9 decreases by approximately $4.5 \%$, and in those with a ratio of 1.0 hardness decreases by $14 \%$.

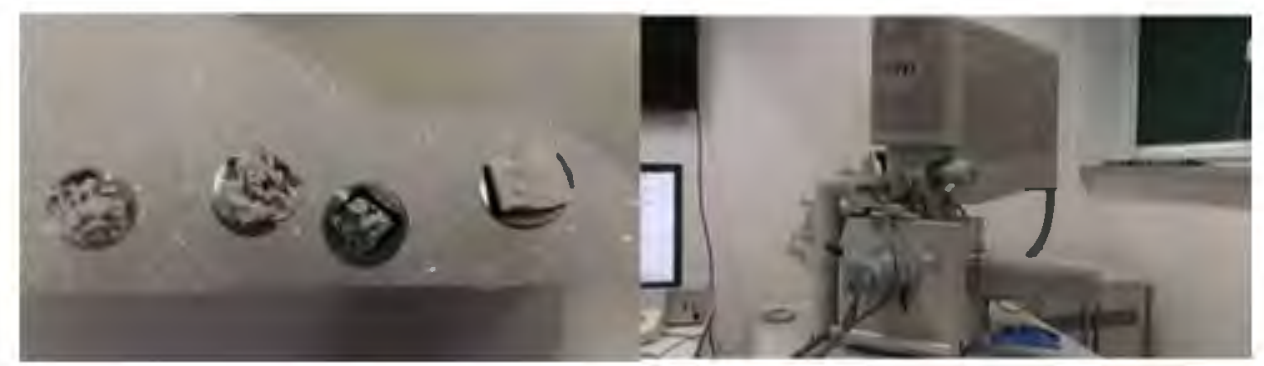

Fig. 9. Microscopy assay (SEM). 

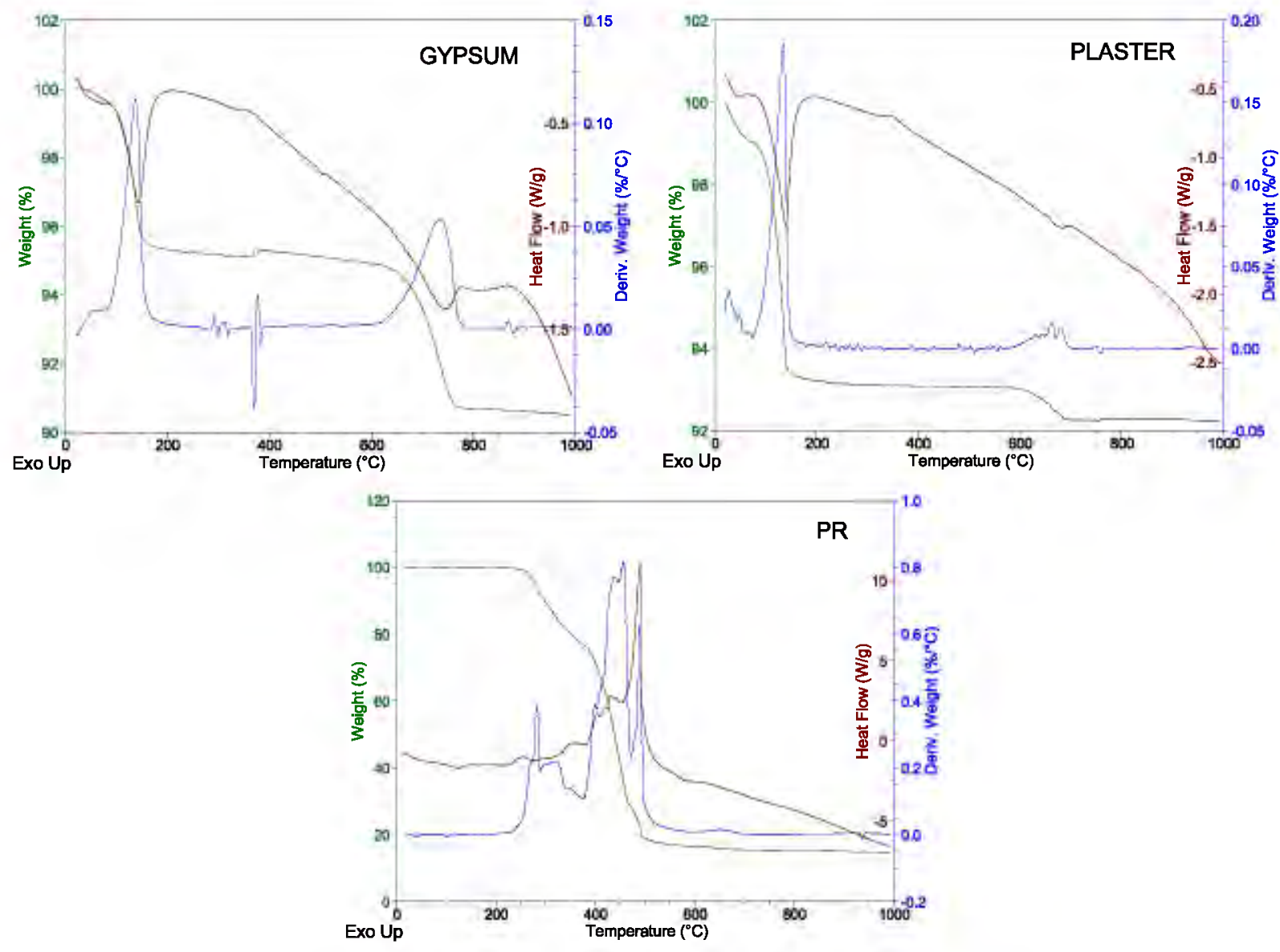

Fig. 11. Thermogravimetric analysis of gypsum, plaster and pellets.

Table 3

Consistency of the pastes ( $\mathrm{mm}$ ).

\begin{tabular}{|c|c|c|c|c|}
\hline$\% \mathrm{PR}$ & Y0.8 & $\mathrm{Y} 1.0$ & E0.8 & E0.9 \\
\hline \multicolumn{5}{|c|}{ Vibrating table method, UNE EN 13279-2 } \\
\hline $50 \%$ & 180.50 & 235.00 & 239.50 & 201.50 \\
\hline $60 \%$ & 134.50 & 183.00 & 174.00 & 195.00 \\
\hline $70 \%$ & 124.50 & 188.50 & 139.50 & 170.50 \\
\hline
\end{tabular}

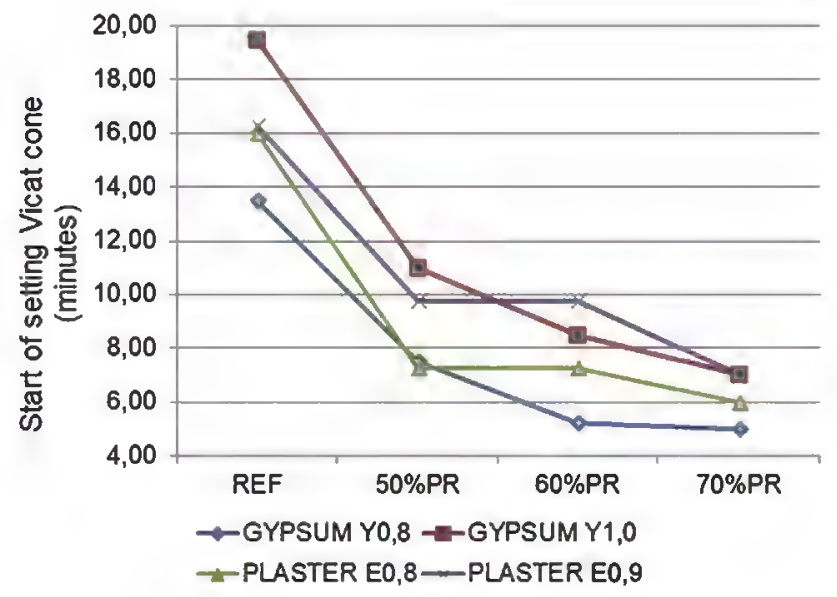

Fig. 12. Start of setting using the Vicat cone penetrometer.

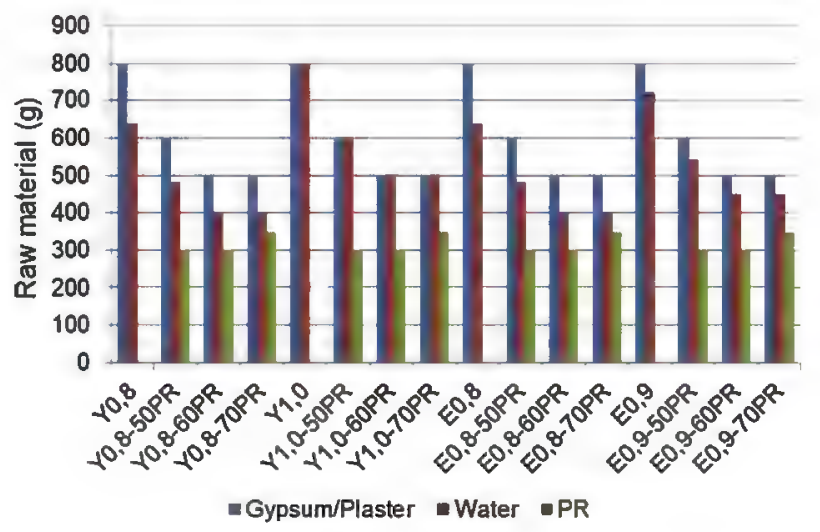

Fig. 13. Raw material used in test samples. 


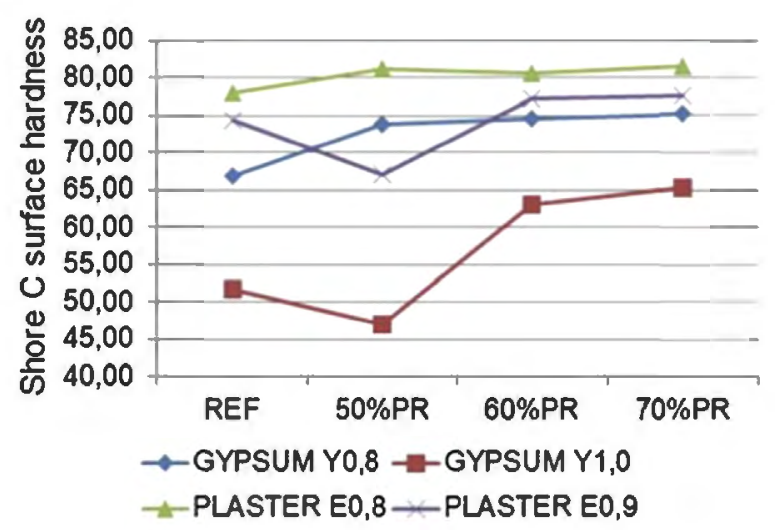

Fig. 14. Shore $C$ surface hardness of compounds.

Generally speaking, surface hardness was higher in the plaster compounds compared with gypsum compounds, due to the nature of the binder. Among compounds made with the same binder, surface hardness was higher in test samples with the lowest water content, in other words, plaster 0.8 and gypsum 0.8 presented higher surface hardness values than plaster 0.9 and gypsum 1.0.

The compound with the highest surface hardness value was $\mathrm{E}$ 0.8-70 PR (81.60) and the one with the lowest value was Y 1.050 PR (47.00).

\subsubsection{Flexural and compressive strength}

Fig. 15 shows the flexural and compressive strength of the test samples after testing.

In the flexural strength test, all the values obtained in mixtures with PR were approximately $50 \%$ lower with respect to reference values, but in all cases remained above the minimum $1 \mathrm{~N} / \mathrm{mm}^{2}$ required in the UNE standard. Flexural strength was largely similar in both plaster and gypsum test samples. Flexural strength decreases as the water content increased, and was up to $12.5 \%$ lower in compounds with a 0.9 ratio, and $38.5 \%$ lower in compounds with a 1.0 ratio. The compound with the highest flexural strength was E $0.8-60 \mathrm{PR}\left(2.63 \mathrm{~N} / \mathrm{mm}^{2}\right)$, and those with the lowest were Y1.0-50PR and Y1.0-70PR $\left(1.51 \mathrm{~N} / \mathrm{mm}^{2}\right)$.

A similar trend was observed in the compressive strength test: values were reduced by half in the PR mixtures with respect to reference values, but in all cases remained above the minimum $2 \mathrm{~N} /$ $\mathrm{mm}^{2}$ required in the UNE standard. In this case, the plaster test samples showed $24.5 \%$ more compressive strength than gypsum compounds. Compressive strength was also affected by water content: pastes with the highest water/gypsum ratio showed lower compressive strength, which decreased by $18.8 \%$ in compounds with a 0.9 ratio, and by $37 \%$ in compounds with a 1.0 ratio. The

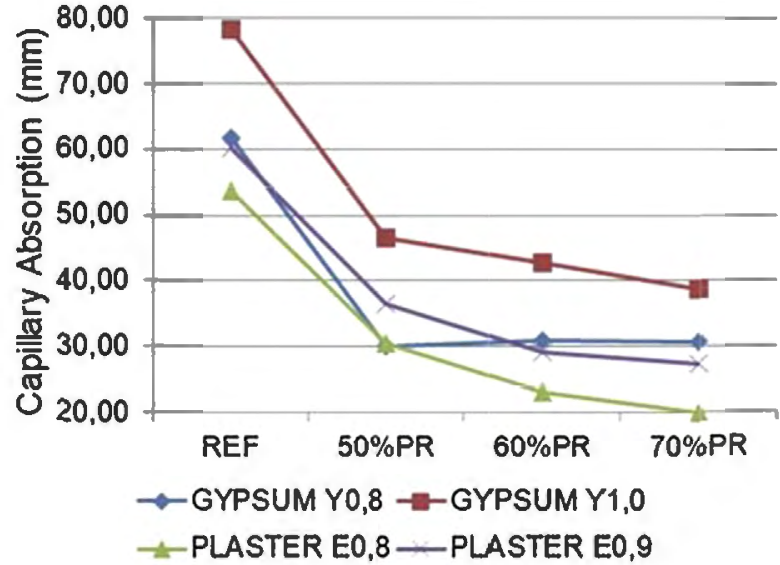

Fig. 16. Capillary absorption values of the compounds

compound with the highest compressive strength was E 0.8 $60 P R\left(2.63 \mathrm{~N} / \mathrm{mm}^{2}\right)$, and that with the lowest was Y1.0-50PR $\left(2.24 \mathrm{~N} / \mathrm{mm}^{2}\right)$.

\subsubsection{Capillary absorption}

The capillary absorption of each compound is shown in Fig. 16.

Generally speaking, capillary absorption decreased by over $50 \%$ with respect to reference values in compounds containing PR.

The plaster pastes showed approximately $20 \%$ less capillarity than those with gypsum. Among test samples made with the same binder, those with a higher water content showed greater capillary absorption, in other words, compared with compounds with a ratio of 0.8 , those with a ratio of 0.9 showed up to $27.4 \%$ more capillarity and those with a ratio of 1.0 showed up to $39.6 \%$ more capillarity. The compound with the lowest capillarity was E 0.8-70 PR (20.00 $\mathrm{mm}$ in $10 \mathrm{~min}$ ) and that with the highest absorption was $\mathrm{Y} 1.0-50$ $\mathrm{PR}(46.50 \mathrm{~mm}$ in $10 \mathrm{~min})$.

\subsubsection{Microscopic analysis}

Fig. 17 shows several microscopic images of compounds with PR. The dihydrate gypsum crystals formed when the hemihydrate is hydrated during setting are seen in the form of needles and plates of less than 5 and $10 \mu \mathrm{m}$. These form a porous framework that envelops the much larger pellet particles. Both continuous gypsum-pellet bonding surfaces with good adhesion and edges with cracks and poor adhesion can be observed between the 2 phases. The pellet phase distributed in the gypsum matrix acts as a barrier to water, which explains the improved absorption properties of compounds with PR. The presence of a certain number of interruptions in the gypsum-pellet bond would explain the diminished mechanical properties with respect to reference values.
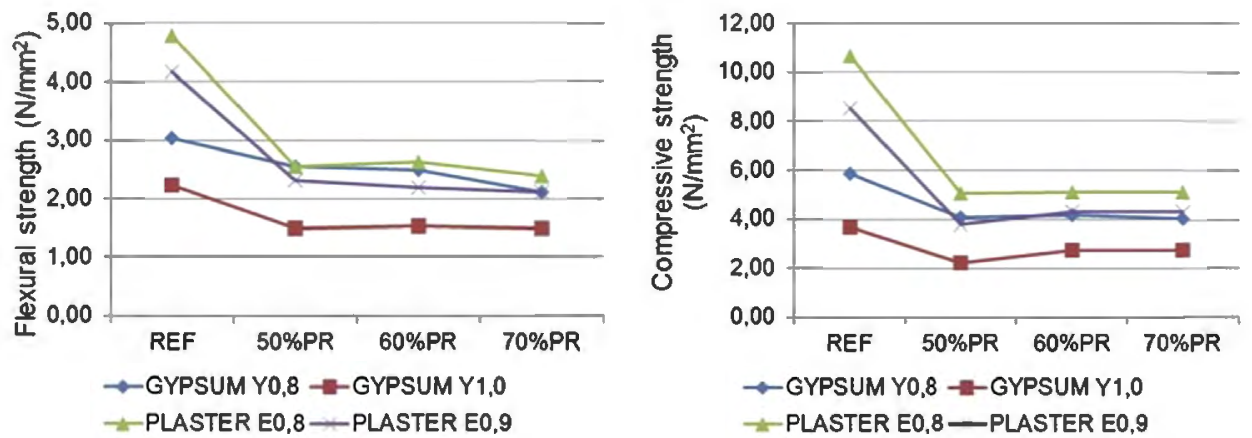

Fig. 15. Flexural and compressive strength of compounds. 

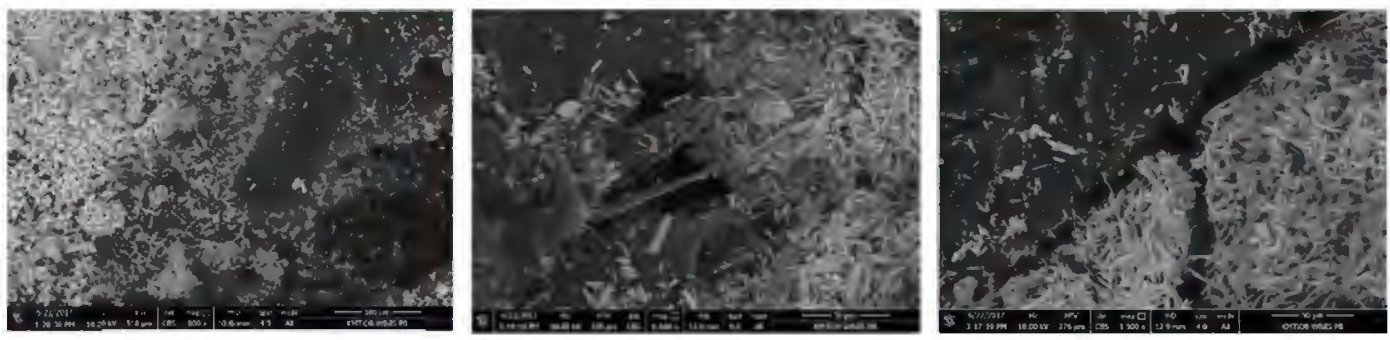

Fig. 17. Microscopic view of a compound with $50 \%$ PR.

\section{Conclusions}

Plastic waste from cables can be used as aggregate in gypsum matrices in proportions of up to $70 \%$. This improves some of the parameters studied, such as surface hardness and water absorption.

The addition of plastic waste also minimises the environmental impact of these building materials by reducing consumption of raw material (raw gypsum) and water, and by re-using waste plastic from cables.

It is advisable to analyse the composition of the PR, because although it is chemically compatible, its heterogeneity must be characterized in detail.

The compounds obtained show less mechanical strength, but meet the minimum requirements of current regulations.

\section{Conflict of interest}

None.

\section{References}

[1] M. del Río Merino, J. Garcia Navarro, P. Villoria Saez, "Legal aspects which implement good practice measures in the management of construction and demolition waste", Open Constr. Build. Technol. J. 5 (Suplem) (2011) 7.

[2] J. López de Asiain, "Arquitectura, Ciudad, Medioambiente" (Kora, no. 11), Sevilla: Universidad de Sevilla, Secretariado de Publicaciones, 2001, p. 214.

[3] R. Merino, M. González Cortina, P. Izquierdo Gracia, J. Santa Cruz Astorqui, I. Salto-Weis Azevedo, "Los nuevos materiales de construcción como alternativa al reciclaje de los residuos industriales: mortero de cemento-caucho reciclado (CCR)", I Jornada de Investigación en Edificación, Escuela Técnica Superior de Edificación de Madrid-UPM, Spain, 2006.

[4] R. Walker, S. Pavia, R. Mitchell, Mechanical properties and durability of hemplime concretes, Constr. Build. Mater. 61 (2014) 340-348.

[5] Eurostat. (2014, 5 de febrero). Waste statistics, http://ec.europa.eu/eurostat/ statistics-explained/index.php/Waste statistics.

[6] R-L. Carmen, J. María, "The influence of natural and synthetic fibre reinforcement on wood-gypsum composites", Open Constr. Build. Technol. J. $11(1)(2017)$

[7] L. Alameda, V. Calderón, J. Gadea, S. Gutiérrez-Gonzáleza, Reciclado de placas de yeso laminado aligeradas con residuos de poliuretano, Anales de Edificación 1 (1) (2015) 33-39

[8] PlasticsEurope. (2016, 4 de febrero). Indicadores de fabricación de plásticos, http://www.plasticseurope.es/.

[9] E. Franco-Urquiza, M.L. Maspoch, "Viabilidad del reaprovechamiento de residuos de PVC provenientes de cables eléctricos: propiedades mecánicas", Afinidad 71 (567) (2014).

[10] L. Gómez-Zamorano, C. Iñiguez-Sánchez, B. Lothenbach, Microestructura y propiedades mecánicas de cementos compuestos: efecto de la reactividad de adiciones puzolánicas e hidráulicas, Alconpat 5 (1) (2015) 18-30.

[11] M.D. Alba Rodríguez, J. Solís-Guzmán, P. Mercader-Moyano, M. Barragân Maestre, "Evaluación global de la recuperación de edificios. Fase 1: Base de datos en soporte ARCGIS", Congreso Internacional de Construcciôn Sostenible y Soluciones Ecoeficientes, Sevilla (Spain), 2013.

[12] A. San-Antonio González, M.D. Río Merino, C. Viñas Arrebola, "Estado de la cuestión sobre compuestos de yeso. La importancia actual de los residuos", Congreso Internacional de Construcción Sostenible y Soluciones Ecoeficientes, Sevilla (Spain), 2013

[13] L. Alameda, V. Calderón, C. Junco, A. Rodríguez, J. Gadea, S. Gutiérrez-González, "Characterization of gypsum plasterboard with polyurethane foam waste reinforced with polypropylene fibers", Materiales de Construcción 66 (324) (2016).

[14] R. Gaggino, R. Arguello, H. Berretta, Aplicación de material plástico reciclado en elementos constructivos a base de cemento, Centro Experimental de la Vivienda Económica, Córdoba (Mêxico), 2007.

[15] E.G. De Los Santos et al., "Estudio de factibilidad bloques de hormigón con agregado de residuo plástico ABS", 11th Latin American and Caribbean Conference for Engineering and Technology, Cancún (México), 2013.

[16] S. Kou, G. Lee, C. Poon, W. Lai, Properties of lightweight aggregate concrete prepared with PVC granules derived from scraped PVC pipes, Waste Manage. 29 (2) (2009) 621-628.

[17] M. J. Panvini et al., "Vinculación tecnológica en hormigones con agregados plásticos reciclados", XXXIV Encuentro Arquisur 2015 y XIX Congreso de Escuelas y Facultades Públicas de Arquitectura de los países de América de] Sur, La Plata (Argentina), 2015.

[18] M. Frigione, Recycling of PET bottles as fine aggregate in concrete, Waste Manage. 30 (6) (2010) 1101-1106

[19] F. Reyes, "Mezclas asfálticas modificados con un elastómero (caucho) y un plastómero (tiras de bolsas de leche con asfalto 80-100),", Infraestructura Vial 10 (17) (2007).

[20] M. Gómez, A. Carvajal, V. Santelices, Influencia del Polietileno de Alta Densidad (PEAD) usado como adición en el mortero de cemento, Revista de la construcción 10 (3) (2011) 110-121.

[21] Z. Ge, R. Sun, K. Zhang, Z. Gao, P. Li, Physical and mechanical properties of mortar using waste Polyethylene Terephthalate bottles, Constr. Build. Mater. 44 (2013) 81-86.

[22] 0. Gencel et al., Properties of gypsum composites containing vermiculite and polypropylene fibers: numerical and experimental results, Energy Build. 70 (2014) 135-144

[23] A. Khali1, A. Tawfik, A. Hegazy, M. El-Shahat, Effect of some waste additives on the physical and mechanical properties of gypsum plaster composites, Constr. Build. Mater. 68 (2014) 580-586.

[24] R. Vicente, T. Silva, Brick masonry walls with PCM macrocapsules: an experimental approach, Appl. Thermal Eng. 67 (1-2) (2014) 24-34.

[25] M. del Río Merino, J. Santa Cruz Astorqui, P. Villoria Sáez, R. Santos Jiménez, "Eco plaster mortars with addition of waste for high hardness coatings", Constr. Build. Mater. 158 (2018) 649-656.

[26] L. d. Villanueva and A. García Santos, Manual del yeso, Asociación Técnica y Empresarial del Yeso, ISBN 8495312468, 2001.

[27] P.V.Sáez, M. del Río Merino, A.S.-A. González, "Material de Construcción Ligero Fabricado Con Yeso y Residuo de Poliestireno Extruido,", Proceedings of the Il International Congress on Sustainable Construction and Eco-Efficient Solutions, Sevilla (Spain), 2015, pp. 443-451.

[28] A. Jiménez Rivero, A.d. Guzmán Báez, J. Garcia Navarro, M. González Cortina, "Nuevos Materiales de Base Yeso con Incorporación de Residuos de Caucho: Caracterización Físico-Mecánica", IX Jornadas Iberoamericanas de Materiales de Construcción, Quito (Ecuador), 2011.

[29] F.J.G. Madariaga, Mezclas de residuos de poliestireno expandido (EPS) conglomerados con yeso o escayola para su uso en la construcción, Informes de la Construcción 60 (509) (2008) 35-43.

[30] A.M. Borreguero, A. Serrano, I. Garrido, J.F. Rodríguez, M. Carmona, Polymeric$\mathrm{SiO}_{2}-\mathrm{PCM}$ for improving the thermal properties of gypsum applied in energy efficient buildings, Energy Conv. Manage. 87 (2014) 138-144.

[31] UNE-EN 13279-1:2009 "Gypsum binders and gypsum plasters. Part 1: Definitions and requirements", Una Norma Española UNE-EN 13279-2, 2009

[32] UNE-EN 13279-2:2014 "Gypsum binders and gypsum plasters. Part 2:Test methods", Una Norma Española UNE-EN 13279-2, 2014

[33] UNE-EN 933-1. "Tests for geometrical properties of aggregates. Part 1: Determination of particle size distribution. Sieving method", Una Norma Española UNE-EN 933-1, 2012.

[34] UNE 102042 "Gypsum plasters. Other test methods", Una Norma Española UNE 102042, 2014.

[35] M. d. Rio Merino, "Elaboración y aplicaciones constructivas de paneles prefabricados de escayola aligerada y reforzada con fibras de vidrio $\mathbf{E}$ y otros aditivos", Ph Dissertation Arquitectura-UPM, 1999.

[36] T. Rilem, Recommended tests to measure the deterioration of stone and to assess the effectiveness of treatment methods, Mater. Struct. 13 (75) (1980) 175-253. 
37] S. Romaniega Piñeiro, "Refuerzo de la escayola mediante fibras de lana mineral procedentes del reciclaje de RCD", Ph. Dissertation Escuela Técnica Superior de Edificación de Madrid-UPM, 2016.

[38] A. San-Antonio-González, M.D.R. Merino, C.V. Arrebola, P. Villoria-Sáez, "Lightweight material made with gypsum and eps waste with enhanced mechanical strength", J. Mater. Civil Eng. 28 (2) (2015).

[39] S.S. Suresh, S. Mohanty, S.K. Nayak, Composition analysis and characterization of waste polyvinyl chloride (PVC) recovered from data cables, Waste Manage. 60 (2017) $100-111$
[40] C. Strydom, J. Potgieter, Dehydration behaviour of a natural gypsum and a phosphogypsum during milling, Thermochimica acta 332 (1) (1999) 89-96.

[41] G.W. Ehrenstein, G. Riedel, P. Trawiel, "Thermal Analysis of Plastics: Theory and Practice", Carl Hanser Verlag GmbH Co KG, 2012.

[42] G. Richard, S. Touhami, T. Zeghloul, L. Dascalescu, Optimization of metals and plastics recovery from electric cable wastes using a plate-type electrostatic separator, Waste Manage. 60 (2017) 112-122. 